\title{
Spatio-temporal distribution of Hylobius abietis in Scots pine stands - implications for pest monitoring
}

\author{
Iwona Skrzecz ${ }^{1}$ (D) $\cdot$ Lidia Sukovata $^{1}$ (D) $\cdot$ Tomasz Jabłoński $^{1}$ (D) $\cdot$ Alicja Sowińska $^{1}$ (D) $\cdot$ Hanna Szmidla $^{1}$ (D)
}

Received: 30 July 2020 / Revised: 29 December 2020 / Accepted: 18 January 2021 / Published online: 15 February 2021

(c) The Author(s) 2021

\begin{abstract}
The protection of reforested areas against the large pine weevil Hylobius abietis is one of the greatest forest management challenges in many European countries. No information exists on the spatial distribution of this pest, which is necessary to assess its abundance and, consequently, to precisely estimate its threat to reforested sites. The aim of this study was to assess the spatio-temporal changes in the number of $H$. abietis beetles in reforested clear-cut areas (reforestations) and neighbouring Pinus sylvestris stands, from which these beetles are assumed to migrate to the reforestations. In this two-year study, baited traps were used to catch $H$. abietis beetles in the reforestations and neighbouring stands. The results revealed significantly more beetles in the neighbouring old stands (61-69 years) than in the young stands (5-11 years). The distribution of the beetles in both the old and young stands was inversely dependent on the distance from the stand edge. The large pine weevil migration to the reforestations was most intense in mid-May and early June. In May, most beetles were collected along the edges of the reforestations; in June, their distribution was more regular; and in July, the beetles were more abundant in the central part of the reforestations. These results allow H. abietis monitoring improvement, which is an important element of integrated forest protection.
\end{abstract}

Keywords Large pine weevil $\cdot$ Reforested areas $\cdot$ Abundance $\cdot$ Baited traps $\cdot$ Integrated management

\section{Key message}

- The spatio-temporal distribution of Hylobius abietis, a pest of forest plantations, was studied in reforestations and neighbouring stands for the first time.

- The beetle distribution in reforestations changed throughout the season from inversely to positively dependent on the distance from their edge, while it was constantly inversely dependent in neighbouring stands.

- The results will contribute to the improvement of pest monitoring and the methods to assess the threat to reforestations.

Communicated by Andrea Battisti.

Iwona Skrzecz

i.skrzecz@ibles.waw.pl

1 Department of Forest Protection, Forest Research Institute, Sękocin Stary, 05-090 Raszyn, Poland

\section{Introduction}

The large pine weevil, Hylobius abietis L. (Coleoptera, Curculionidae), is one of the most dangerous pests to 1 - to 3-year-old coniferous reforestations established in clear-cut areas (Day et al. 2004). This insect can damage seedlings of all coniferous species and certain species of deciduous trees (Manlove et al. 1997; Toivonen and Viiri 2006; Wallertz et al. 2014).

Hylobius abietis has been the subject of numerous studies for many decades; hence, its biology, ecology and pest status are well known (Munro 1928, 1929; Bejer-Petersen et al. 1962; Christiansen 1971; Nordenhem 1989; Leather et al. 1999; Day et al. 2004; Långstróm and Day 2004). The duration of $H$. abietis development depends mainly on the microclimate and the quality of breeding sites (Wilson et al. 1996; Von Sydow and Birgersson 1997; Leather et al. 1999; Thorpe and Day 2002). The beetles emerge from wintering sites when the air temperature reaches $8-10{ }^{\circ} \mathrm{C}$, usually from early April to mid-May (Munro 1928; Nordenhem 1989). They move to clear-cut areas, as they are attracted by the monoterpenes in the resin emitted by conifer stumps 
left after tree felling (Tilles et al. 1986; Nordenhem and Eidmann 1991; Schlyter 2004). There are two peaks of pest occurrence in clear-cut areas. The first peak usually occurs from late May to early June. It results from the intensification of the flight activity of $H$. abietis beetles at temperatures above $18.0^{\circ} \mathrm{C}$ (Solbreck and Gyldberg 1979). After maturation feeding, the females lay eggs (June-July) on the roots of coniferous stumps or in the soil close to these roots (Nordlander et al. 2003a). Fresh conifer stumps, mainly of Pinus sylvestris L. and Picea abies (L.) H. Karst, are the most important breeding materials for $\mathrm{H}$. abietis beetles. However, the thicker branches of coniferous trees and pieces of bark together with their inner phloem on the ground also provide a breeding base for the complete development of the large pine weevil. After egg hatching, the larvae feed on and create tunnels between the cambium and inner bark. Larval development lasts up to 12 weeks and depends primarily on the temperature of the soil hosting its breeding base. Larvae pupate in pupal chambers at the end of the feeding tunnels. After emerging, the majority of beetles remain in the pupal chambers, where they overwinter, while some of them leave the pupal chambers from August-September (the second peak of occurrence) (Nordenhem 1989). In Poland, the time needed to complete one $H$. abietis life cycle from egg to adult usually lasts from June-September (Dominik 1958; Korczyński 1992). Under adverse microclimatic conditions, the development may be extended to April-May of the next year (Dominik 1958; Kuziemska-Grzeczka 1984). Under the less favourable climatic conditions of Scandinavia or the UK, the duration of one generation can be extended to 3-5 years, although $75 \%$ of large pine weevils develop within 1 year (Bejer-Petersen et al. 1962; Långstrőm 1982; Leather et al. 1999).

The population abundance of large pine weevils in reforested clear-cut areas (reforestations) is usually assessed on the basis of the number of beetles caught in various types of traps, including traps made from cut Scots pine trees (pine billets), in which the monoterpenes in the resin ( $\alpha$-pinene and ethanol) attract $H$. abietis beetles, and artificial traps with an attractant containing the compounds mentioned above (Wilson and Day 1995; Långstróm and Day 2004; Skrzecz 2017). The first artificial trap, a pot placed in soil into which beetles can fall, was developed in Sweden in the 1980s (Nordlander 1987). Swedish traps with various modifications have been employed in several European countries to monitor H. abietis abundance (Zumr and Starý 1993; Wilson and Day 1995; Eidmann 1997; Olenici et al. 2016). In Great Britain, another trap was developed to monitor the numbers of $H$. abietis beetles and their parasitoid Bracon hylobii Ratz (Moore 2001). The trap resembled a tent stretched on a tripod and was placed above a stump. This trap type allows the number of beetles emerging from a stump to be assessed. In Poland, changes in the number of $\mathrm{H}$. abietis beetles were observed using either pine billets or IBL-4 traps (Chemipan R\&D Laboratories, Warsaw, Poland) (Fig. 1) (Skłodowski and Gadziński 2001; Skrzecz 2001, 2017). The IBL-4 trap is a plastic pipe that is $60 \mathrm{~cm}$ long and $10 \mathrm{~cm}$ wide, with two rows of inlaid holes. Short plastic funnels are inserted in the holes to prevent the beetles from escaping the trap. The trap is baited with a mixture of $\alpha$-pinene and ethanol, which works as a food attractant.

Although much work has been conducted on H. abietis, methods for the precise assessment of the threat from this pest to reforestations have not yet been developed. This failure may be explained by the large number of factors influencing the spread of the large pine weevil, including the availability of breeding sites, the rate of pest development under local microclimatic conditions, the timings of felling and replanting, and the types of stands surrounding the clear-cut areas (Wilson et al. 1996; Leather et al. 1999; Inward et al. 2012). In the available literature, information on the spatial distribution of $H$. abietis in coniferous stands is very limited. The research conducted to date has mainly focused on the changes in the pest number in reforestations under the influence of various, primarily environmental, factors (Christiansen and Bakke 1971; Solbreck and Gyldberg 1979; Långström 1982; Nordlander et al. 2003b; Daegan et al. 2012). Långström (1982) studied the abundance of $H$. abietis in reforestations located in different regions of Finland. In Sweden, Örlander et al. (1997) observed the population dynamics and damage caused by large pine weevils over six years following replanting. The impact of the withinyear felling date on the number of $\mathrm{H}$. abietis beetles and the extent of damage to seedlings was studied by Korczyński (1984) and Moore et al. (2004). In addition, many observations regarding the estimation of large pine weevil abundance have been based on beetle catches in traps primarily laid out in the central part of clear-cut areas (Szmidt and

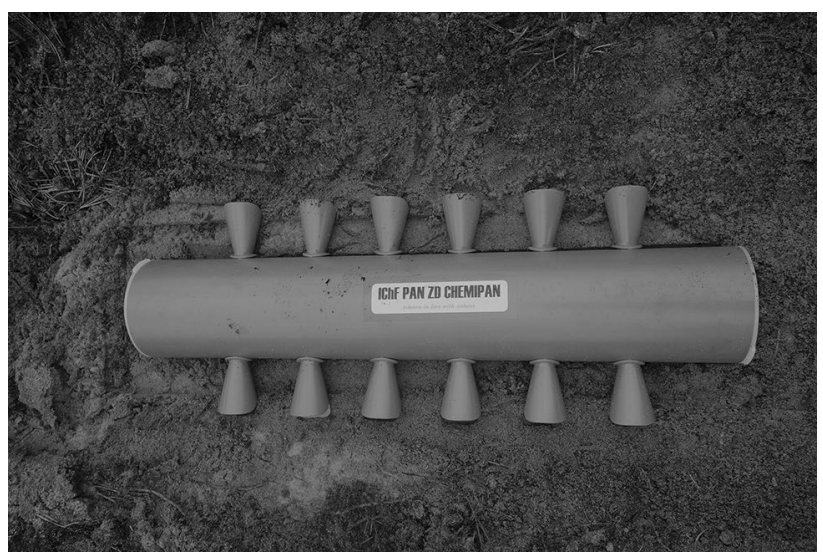

Fig. 1 IBL-4 traps implemented in Poland to monitor H. abietis populations 
Korczyński 1982; Zumr and Stary 1995; Örlander et al. 1997; Olenici et al. 2016; López-Villamor et al. 2019).

The aim of this study was to determine the seasonal spatio-temporal distribution of the large pine weevil in reforestations and surrounding stands of different age. Two research hypotheses were considered. The first hypothesis was that during the growing season, the $H$. abietis populations in reforested clear-cut areas are not evenly distributed, and the beetles are more abundant close to the neighbouring stands. If confirmed, this would indicate that the beetles migrate to the reforestations from those stands. The second hypothesis was that more beetles migrate to the reforestations from old neighbouring stands than from young neighbouring stands.

\section{Materials and methods}

\section{Study sites}

The study was conducted from 2015-2016 in two forest districts, namely, Garwolin and Koniecpol, where Scots pine forests dominate $(>70 \%)$. The Garwolin Forest District is located in central Poland, with a mean annual temperature of $+7.5^{\circ} \mathrm{C}$. The precipitation ranges from 550 to $600 \mathrm{~mm}$ per year, and winter lasts 90-110 days, while the growing season is approximately 200-210 days long. The main forest-forming species are $P$. sylvestris (75\%), Norway spruce (P. abies) (10\%), common oak (Quercus robur L.) (8\%) and black alder (Alnus glutinosa L.) (7\%). The Koniecpol Forest District is located approximately $200 \mathrm{~km}$ from the Garwolin Forest District in the southern part of Poland with a mean annual air temperature of $+8{ }^{\circ} \mathrm{C}$. The precipitation ranges from 600 to $700 \mathrm{~mm}$ per year, and winter lasts 70-90 days. The growing season is slightly longer than that in the Garwolin Forest District and lasts approximately 210-220 days.
Pinus sylvestris (73\%), Q. robur (20\%) and P. abies (7\%) are the most important forest tree species in this area. In both Forest Districts, podzol soils and rusty podzol soils prevail.

Every year in each forest district, one reforestation, one neighbouring young stand and one neighbouring old stand were selected for observation. The clear-cut areas were created after removing 100- to 120-year-old P. sylvestris stands, and in March of the next year, they were reforested mainly with 2-year-old seedlings of $P$. sylvestris (Table 1). No chemical treatments were implemented in these areas. The young stands and old stands were 5-11 and 61-69 years old, respectively (Table 2). No cleaning or thinning cuts in those stands, respectively, were performed 2 years prior to the study to eliminate the possible impact of fresh stumps on $H$. abietis number.

Data on the climatic conditions in both forest districts were obtained from the Polish Institute of Meteorology and Water Management-National Research Institute. Data on the characteristics of the forests and site conditions were obtained from the forest districts. The mean daily air temperatures from April to September at the study sites (useful for the interpretation of $H$. abietis capture dynamics) were obtained from local meteorological stations of the State Forests.

\section{Experimental design}

IBL-4 traps with Hylodor attractant composed of $\alpha$-pinene and ethanol (Chemipan R\&D Laboratories, Warsaw, Poland) were applied in this study. The experiments were established on 12-14 April in 2015 and 2016, before the start of $\mathrm{H}$. abietis migration. Two arrangements of traps were implemented at each experimental site. The traps were set up along two transects from the edge between the reforestation and either the young stand or old stand in two opposite directions:

Table 1 Characteristics of the experimental reforested clear-cut areas

\begin{tabular}{|c|c|c|c|c|c|}
\hline Forest district & Study year & Location & $\begin{array}{l}\text { Date of clear-cut area estab- } \\
\text { lishment and reforestation }\end{array}$ & Area (ha) & $\begin{array}{l}\text { Tree species composition of the } \\
\text { reforestations and the share of spe- } \\
\text { cies }(\%)\end{array}$ \\
\hline \multirow[t]{4}{*}{ Garwolin } & 2015 & $51^{\circ} 52^{\prime} 13.5 " \mathrm{~N}$ & October, 2014 & 3.86 & P. sylvestris -70 \\
\hline & & $21^{\circ} 25^{\prime} 51.2^{\prime \prime} \mathrm{E}$ & March, 2015 & & $\begin{array}{l}\text { Q. robur }-20 \\
\text { B. pendula }-10\end{array}$ \\
\hline & 2016 & $51^{\circ} 52^{\prime} 52.6^{\prime \prime} \mathrm{N}$ & October, 2015 & 3.37 & P. sylvestris -100 \\
\hline & & $21^{\circ} 23^{\prime} 17.9^{\prime \prime} \mathrm{E}$ & March, 2016 & & B. pendula - singly \\
\hline \multirow[t]{5}{*}{ Koniecpol } & 2015 & $50^{\circ} 47^{\prime} 19.3 " \mathrm{~N}$ & November, 2014 & 3.51 & P. sylvestris -70 \\
\hline & & $19^{\circ} 43^{\prime} 21.1^{\prime \prime E}$ & March, 2015 & & Q. robur -30 \\
\hline & & & & & F. sylvatica - singly \\
\hline & 2016 & $50^{\circ} 46^{\prime} 23.7 " \mathrm{~N}$ & November, 2015 & 3.75 & P. sylvestris -100 \\
\hline & & $19^{\circ} 43^{\prime} 08.1 " \mathrm{E}$ & March, 2016 & & \\
\hline
\end{tabular}


Table 2 Characteristics of the young and old stands neighbouring the experimental reforested clear-cut areas

\begin{tabular}{|c|c|c|c|c|c|c|c|}
\hline \multirow[t]{2}{*}{ Forest district } & \multirow[t]{2}{*}{ Study year } & \multirow[t]{2}{*}{ Type of stand } & \multirow[t]{2}{*}{ Age (years) } & \multirow[t]{2}{*}{ Species composition and share $(\%)$} & \multicolumn{2}{|l|}{ P. sylvestris } & \multirow[t]{2}{*}{ Shrub layer } \\
\hline & & & & & $\mathrm{DBH}^{*}(\mathrm{~cm})$ & Height (m) & \\
\hline \multirow[t]{4}{*}{ Garwolin } & \multirow[t]{2}{*}{2015} & Old stand & 69 & $\begin{array}{l}\text { P. sylvestris }-90 \\
\text { B. pendula }-10 \\
\text { Singly: A. glutinosa } \\
\text { Q. robur }\end{array}$ & 27 & 23 & $\begin{array}{l}\text { F. alnus } \\
\text { P. sylvestris, } \\
\text { Q. robur } \\
\text { J. communis }\end{array}$ \\
\hline & & Young stand & 5 & P. sylvestris -90 & 1 & 2 & - \\
\hline & \multirow[t]{2}{*}{2016} & Old stand & 66 & $\begin{array}{l}\text { P. sylvestris }-80 \\
\text { B. pendula }-20 \\
\text { Singly: } Q . \text { robur }\end{array}$ & 21 & 19 & $\begin{array}{l}\text { F. alnus } \\
\text { B. pendula, } \\
\text { J. communis } \\
\text { P. serotina }\end{array}$ \\
\hline & & Young stand & 10 & $\begin{array}{l}\text { P. sylvestris }-80 \\
\text { B. pendula }-20 \\
\text { Singly: } F \text {. sylvatica } \\
\text { P. abies }\end{array}$ & 3 & 3 & $\begin{array}{l}Q . \text { robur } \\
P . \text { serotina }\end{array}$ \\
\hline \multirow[t]{4}{*}{ Koniecpol } & \multirow[t]{2}{*}{2015} & Old stand & 67 & $\begin{array}{l}\text { P. sylvestris }-100 \\
\text { Singly: } P \text {. abies } \\
\text { B. pendula, } Q \text {. robur }\end{array}$ & 28 & 25 & $\begin{array}{l}\text { Q. robur } \\
\text { F. alnus } \\
\text { J. communis } \\
\text { P. abies }\end{array}$ \\
\hline & & Young stand & 11 & $\begin{array}{l}\text { P. sylvestris }-80 \\
\text { B. pendula }-10 \\
\text { Q. robur }-10 \\
\text { Singly: } L . \text { decidua, } \\
\text { F. sylvatica }\end{array}$ & 4 & 3 & $\begin{array}{l}\text { B. pendula } \\
\text { F. alnus }\end{array}$ \\
\hline & \multirow[t]{2}{*}{2016} & Old stand & 61 & $\begin{array}{l}\text { P. sylvestris }-100, \\
\text { Singly: } F \text {. sylvatica, } \\
\text { Q. robur, A. alba, } \\
\text { P. abies, } \text { L. decidua }\end{array}$ & 31 & 26 & $\begin{array}{l}\text { A. alba, } \\
\text { Q. robur } \\
\text { B. pendula } \\
\text { P. abies }\end{array}$ \\
\hline & & Young stand & 7 & $\begin{array}{l}\text { P. sylvestris }-80 \\
\text { B. pendula }-20 \\
\text { Singly: } Q . \text { robur, } \\
\text { T. cordata, } F \text {. sylvatica }\end{array}$ & 2 & 2 & - \\
\hline
\end{tabular}

*Diameter at breast height

towards the centre of the reforestation (first transect) and towards the centre of either the young stand or old stand (second transect) (Fig. 2). The reforestation neighbouring either the old stand or young stand is hereafter referred to as reforestation-by-old stand or reforestation-by-young stand, respectively. Each arrangement consisted of 50 traps in the reforestation and 50 traps in the neighbouring young stand or old stand, i.e., 5 repetitions of each transect containing 5 traps. The distance between traps along the transects and between the transects was $10 \mathrm{~m}$.

The traps were checked and emptied every two weeks from April to September of each year. The captured insects were not released at the site but were taken to the laboratory for additional studies not covered in this paper. In mid-July, all attractants were replaced. The observations in each study area were conducted over one growing season. This type of trap setting, ensuring the observation of the changes in beetle numbers up to $50 \mathrm{~m}$ towards the centre of the reforestations and neighbouring stands, allowed an assessment of the temporal changes in the spatial distribution of the large pine weevil population, and consequently, our research hypotheses could be tested.

\section{Statistical analyses}

To compare the data from the trap inspections in the different years, the exact dates were changed into the periods of early May, mid-May, early June, mid-June, early July, mid-July, early August, mid-August, early September and mid-September. The data collected in April, August and September were excluded from the analyses due to the very low abundances of the large pine weevil at all but one site (the Koniecpol Forest District in 2016). 


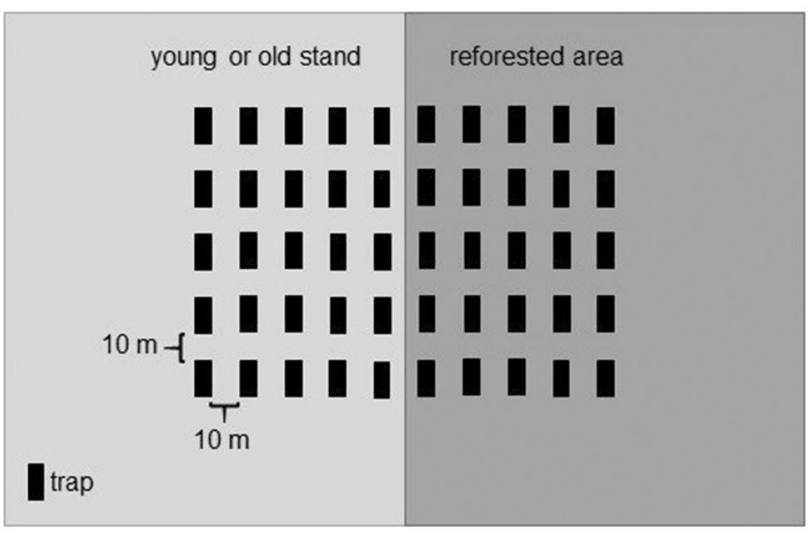

Fig. 2 Arrangement of the IBL-4 traps to catch H. abietis beetles in the reforested clear-cut areas and adjacent young or old stands

The analyses were conducted separately for (1) the two reforestation types-reforestation-by-old stand and reforestation-by-young stand and (2) the two stand types-old stand and young stand. In the first case, the analyses tested the effect of the type of neighbouring stand on the distribution of the weevils in the reforestation, i.e., the catches at the different distances $(10,20,30,40$ and $50 \mathrm{~m})$ from the stands in the different periods of a year. In the second case, the abundance and distribution of the weevils inside the different types of stands were analysed as a function of the distance from the edge of the reforestation in the different periods.

The number of beetles in the traps (the response variable) was highly variable count data. Therefore, the analyses were conducted using a generalized linear mixed model (GLMM) with a negative binomial (NB) error distribution and the log link function. The explanatory fixed variables in the model were (1) stand type, (2) period of the year, (3) distance from the stand edge (in the analyses of reforestation types) or distance from the reforestation edge (in the analyses of stand types), and (4) all two-way interactions. The transects in each of the four plots (the two plots in 2015 and the two other plots in 2016) were given unique numbers, and transect number was included in the model as a random factor. The year of the experiments was not considered a fixed variable but was reflected in this random factor. The significance of the fixed variables and their interactions was tested with a Wald $\chi^{2}$ test (Bolker et al. 2009).

All analyses were conducted in the $\mathrm{R}$ environment, version 3.5.1 (R Core Team 2018), with RStudio, version 1.1.463 (R Studio Team 2016). The following R packages were used: glmmTMB (Brooks et al. 2017) for the NB GLMM and the Wald $\chi^{2}$ test and emmeans (Lenth, 2020) for the multiple mean comparisons. The model goodness of fit was estimated by evaluation of the overdispersion and residual diagnostics (Zuur et al. 2009; Mangiafico 2016). Figures were plotted using the emmeans and ggplot2 packages (Wickham 2016). The significance level was set to $\alpha=0.05$ for all analyses.

\section{Results}

\section{Dynamics of the $\mathrm{H}$. abietis catches in the traps in the study areas in $\mathbf{2 0 1 5}$ and 2016}

Detailed data on the beetle catches (mean \pm standard error) in the traps and the mean daily air temperature in 2015 and 2016 are provided in Online Resources $1 \mathrm{a}$ and $1 \mathrm{~b}$, respectively.

In the second half of April of both years, the mean daily temperature ranged from $4-12{ }^{\circ} \mathrm{C}$, and no beetles were captured. The first beetles were observed in the traps at the beginning of May when the mean daily temperature exceeded $11{ }^{\circ} \mathrm{C}$ and reached $18{ }^{\circ} \mathrm{C}$ in 2015 and $20^{\circ} \mathrm{C}$ in 2016. The highest catches of beetles were noted in either mid-May or June, with the mean daily temperature ranging from $15{ }^{\circ} \mathrm{C}$ to $24{ }^{\circ} \mathrm{C}$ in 2015 and reaching $22{ }^{\circ} \mathrm{C}$ in 2016 (Online Resources 1a and 1b). In the reforestations-by-old stand, the catches varied between $9.8 \pm 0.70$ beetles/trap in the Garwolin Forest District in 2015 and $66.2 \pm 6.10$ beetles/trap in the Koniecpol Forest District in 2016, whereas in the reforestations-by-young stands, they ranged from $3.6 \pm 0.66$ beetles/trap in 2015 to $61.5 \pm 6.00$ beetles/trap in 2016, both in the Garwolin Forest District. In the stands, the maximum catches were generally much lower. In the old stands, they were between $9.1 \pm 1.01$ beetles/trap in the Garwolin Forest District in 2015 and $15.4 \pm 2.86$ beetles/trap in the Koniecpol Forest District in 2016. In young stands, the maximum catches ranged from $0.8 \pm 1.01$ beetles/trap in the Garwolin Forest District in 2015 to $13.9 \pm 2.78$ beetles/trap in the Koniecpol Forest District in 2016.

In July of both years, with the mean daily temperature varying between $15{ }^{\circ} \mathrm{C}$ and $26^{\circ} \mathrm{C}$, the large pine weevil catches were generally much lower (from 0-35.3 \pm 2.21 beetles/trap) than those in June, and in early August, they dropped to zero at most of the study sites (Online Resource $1)$.

The second pest occurrence peak was observed in early September in 2015 and in late August in 2016. August of 2015, particularly the first half, was extremely warm, with a mean daily temperature up to $28^{\circ} \mathrm{C}$ in the experimental areas, whereas in 2016 , it was slightly cooler, with a mean daily temperature oscillating between $13{ }^{\circ} \mathrm{C}$ and $24^{\circ} \mathrm{C}$. Surprisingly, at only one site-the Koniecpol Forest District in 2016 - the weevil catches during the second pest occurrence 
peak period were high (up to $45.0 \pm 3.4$ beetles/trap in the reforestations and $4.1 \pm 0.66$ beetles/trap in the neighbouring stands).

In mid-September, no weevils were captured in the traps.

\section{Distribution of $\mathrm{H}$. abietis in the reforested clear-cut areas}

Among the tested variables (type of neighbouring stand, period, distance from the stand and two-way interactions), period and its interaction with distance had a significant effect on the weevil abundance in the reforestations (Table 3). The interaction between the type of neighbouring stand and distance was nearly significant (Table 3 ) and was not excluded from the model.

The interaction between period and distance from the stands revealed an interesting pattern. In early and midMay, the number of beetles in the reforestations (regardless

Table 3 Outcomes of the Wald chi $^{2}$ test for the effect of the fixed variables and their two-way interactions on the number of $H$. abietis beetles in the traps located in the reforestations neighbouring the old or young stands (the final model does not include the insignificant interaction between period and stand type)

\begin{tabular}{llll}
\hline Fixed variables & df & chi $^{2}$ & $p$ value \\
\hline Type of stand & 1 & 1.97 & 0.1604 \\
Period & 5 & 594.46 & $<0.0001$ \\
Distance & 1 & 0.0008 & 0.9779 \\
Type of stand $\times$ distance & 1 & 3.16 & 0.0754 \\
Period $\times$ distance & 5 & 19.94 & 0.0013 \\
\hline
\end{tabular}

of the neighbouring stand type) decreased with increasing distance from the stands; i.e., the weevils were more abundant close to the edge of the stand (test results for the slopes of the regression lines: early May- $\mathrm{t}=-2.98, \mathrm{df}=1184$, $P=0.0030$; mid-May- $\mathrm{t}=-1.90, \mathrm{df}=1184, P=0.0582)$. In early and mid-June, the distribution of the beetles was more regular, with very slight positive and negative trends, respectively, whereas starting from early July, the relationship between the beetle catches and the distance from the stands became positive (the regression slope was significant only in early July: $\mathrm{t}=2.19, \mathrm{df}=1184, P=0.0285$ ) (Fig. 3). The slopes of the regression lines differed significantly between early May and early July and between early May and midJuly (Fig. 3). In addition, the differences were nearly significant between early May and early June $(\mathrm{t}=-2.76, \mathrm{df}=1184$, $P=0.0711)$ and between mid-May and early July $(\mathrm{t}=-2.88$, $\mathrm{df}=1184, P=0.0518)$.

The nearly significant interaction between the type of neighbouring stand and distance suggests a difference in the general trends (regardless of the period) of the changes in the beetle catches between the reforestations neighbouring old stands and young stands with increasing distance from the stand. In the reforestations-by-old stand, the trend was slightly positive (the slope of the regression line was not significant), whereas in the reforestations-by-young stands, the trend was instead negative (the slope was nearly significant $-\mathrm{t}=-1.79, \mathrm{df}=1184, P=0.0732)$. This difference was caused by the different patterns of the seasonal dynamics in the beetle catches in each type of reforestation (Online Resource 2). In the reforestations-by-old stand, the relationship between the number of weevils and the distance from
Fig. 3 The effect of the interaction between period of the year and distance from the edge of the stands on the number of $H$. abietis beetles ( \pm confidence interval (CI)) captured in the traps set up in the reforested area (different letters indicate significant differences between the slopes of regression lines at $\alpha=0.05$; NB_GLMM followed by contrast tests)

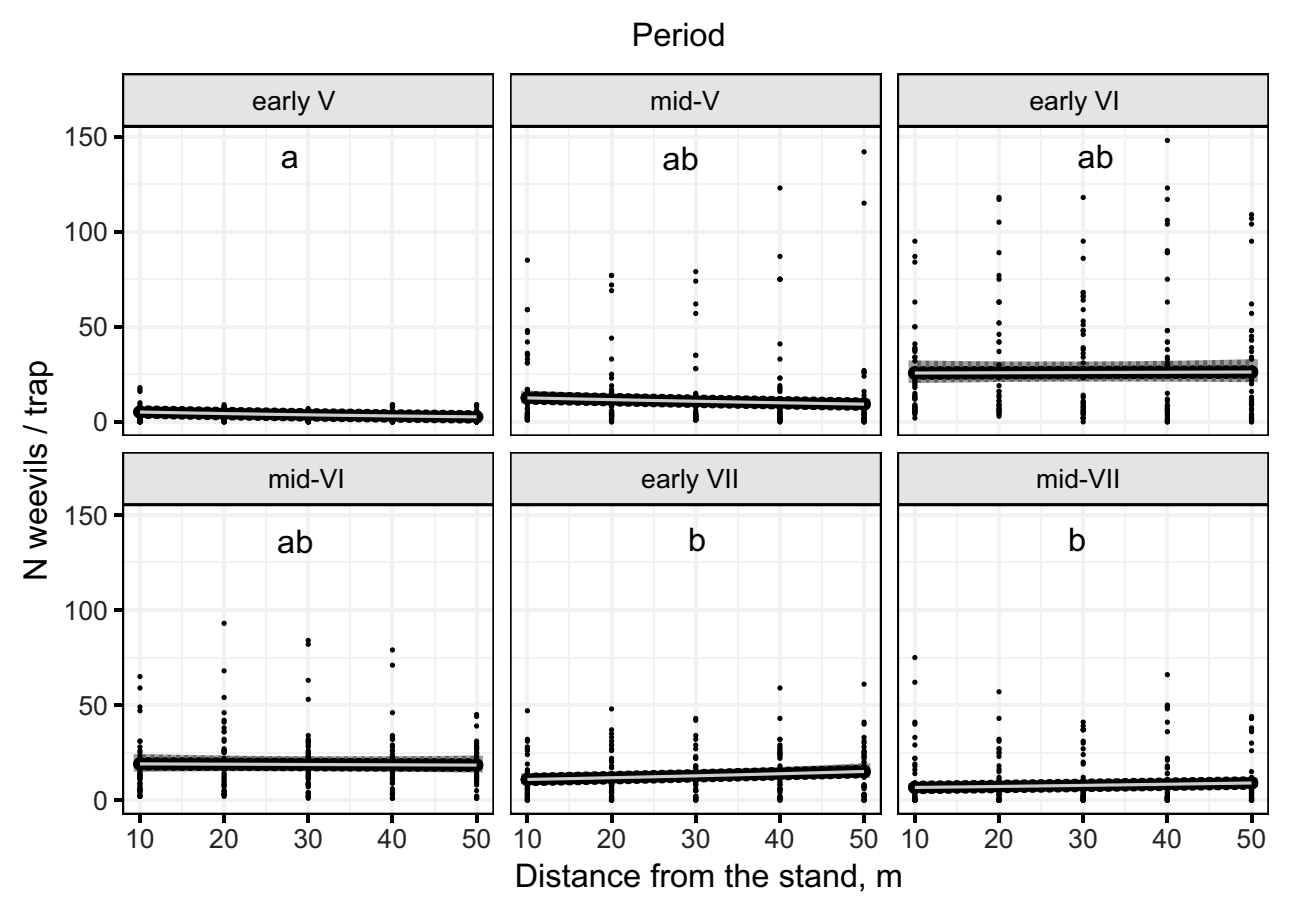


the stand edge was negative in early and mid-May, while in the other periods, it was positive. In the reforestations-byyoung stands, a negative relationship was observed in May but also in both June terms, and only in July did the relationship become positive.

\section{Distribution of $\mathrm{H}$. abietis in the different types of stands}

All tested variables (type of stand, period and distance from the reforestation) and their two-way interactions had a significant effect on the number of weevils in the traps (Table 4).

The overall beetle catches in the old stands $(4.6 \pm 0.19$ beetles/trap) were higher than those in the young stands $(2.8 \pm 0.11$ beetles/trap). The difference was significant in all periods except mid-July (Fig. 4a).

The catches in the traps in both the old stands and young stands (regardless of the period) were inversely dependent on the distance from the border to the reforestation (the test results for the slopes of the regression lines: $\mathrm{t}=-11.47$, $\mathrm{df}=1179, P<0.0001$ and $\mathrm{t}=-12.845$, df $=1179$, $P<0.0001$, respectively), although the slope of the regression line in the old stands was significantly steeper than that in the young stands (Fig. 4b). This result implies that the abundance of weevils in the old stands along the edges bordering the reforestation was much higher than that in the young stands.

The dependency of the beetle catches on the distance from the reforestation (regardless of the stand type) was inverse and significant in all study periods (the test results for the slopes of the regression lines: early May- $t=-6.22$, $\mathrm{df}=1179, P<0.0001 ;$ mid-May- $\mathrm{t}=-12.74, \mathrm{df}=1179$, $P<0.0001$; early June $-\mathrm{t}=-8.97, \mathrm{df}=1179, P<0.0001$; mid-June- $\mathrm{t}=-6.89, \mathrm{df}=1179, P<0.0001$; early July$\mathrm{t}=-5.89, \mathrm{df}=1179, P<0.0001 ;$ mid-July $-\mathrm{t}=-2.62$, $\mathrm{df}=1179, P=0.0089)$. The dependency was most pronounced in mid-May, when the slope of the regression line was significantly steeper than that in all the other periods (Fig. 4c). In contrast, the slope of the regression line in mid-July was the shallowest and differed significantly not

Table 4 Outcomes of the Wald $\mathrm{chi}^{2}$ test for the effect of the fixed variables and their two-way interactions on the number of $\mathrm{H}$. abietis beetles in the traps located in the old and young stands

\begin{tabular}{llll}
\hline Fixed variables & df & chi $^{2}$ & $p$ value \\
\hline Type of stand & 1 & 11.28 & 0.0008 \\
Period & 5 & 246.11 & $<0.0001$ \\
Distance & 1 & 307.52 & $<0.0001$ \\
Type of stand $\times$ distance & 1 & 6.08 & 0.0137 \\
Period $\times$ distance & 5 & 50.10 & $<0.0001$ \\
Type of stand $\times$ period & 5 & 78.28 & $<0.0001$ \\
\hline
\end{tabular}

only from that in mid-May but also from those in early June and mid-June, and the differences from those in early May and early July were nearly significant $(\mathrm{t}=-2.59, \mathrm{df}=1179$, $P=0.0679$ and $\mathrm{t}=-2.64, \mathrm{df}=1179, P=0.0679$, respectively) (Fig. 4c).

\section{Discussion}

The temporal changes in $H$. abietis abundance during the growing season were consistent with those reported in other studies (Långström 1982; Nordenhem 1989; Zumr and Starý 1994; Leather et al. 1995; Örlander et al. 1997). The appearance of beetles in clear-cut areas depends on weather conditions, particularly air temperature (Christiansen and Bakke 1968; Havukkala and Selander 1976; Solbreck and Gyldberg 1979; Day et al. 2004). In our study, the beetles did not appear in the traps until the beginning of May, when the mean daily temperature exceeded $10^{\circ} \mathrm{C}$. These results confirmed earlier reports by Korczyński (1992) that in Poland, $H$. abietis emerges from overwintering places when the air temperature exceeds $10^{\circ} \mathrm{C}$, which usually occurs at the turn of April and May. Additionally, Eidmann (1974) and Nordenhem (1989) stated that $H$. abietis beetles terminate their winter hibernation period when the temperature ranges from 8 to $10{ }^{\circ} \mathrm{C}$. The period of pest migration to clear-cut areas is often extended because the individuals that overwintered in warm (sunny) locations appear earlier than those that overwintered at cool (shaded) locations (Christiansen 1971; Solbreck and Gyldberg 1979; Kuziemska-Grzeczka 1984). An increase in temperature to above $15{ }^{\circ} \mathrm{C}$ accelerates the rate at which beetles emerge from their overwintering places. Solbreck and Gyldberg (1979) showed that temperatures above $18{ }^{\circ} \mathrm{C}$ favoured the intensification of the flight activity and thus the migration of beetles to clear-cut areas. Such temperature conditions, which usually occur at some point from May-June, lead to increased and synchronized pest migration. These observations were also confirmed by our research, in which the number of large pine weevils in the traps substantially increased when the mean daily temperature exceeded $15^{\circ} \mathrm{C}$.

In our study, the largest numbers of beetles were observed in the traps in the second half of May and the first half of June. These results confirmed the observations often reported by other authors (e.g.Långström 1982; Zumr and Starý 1994; Day et al. 2004). Under warm summer conditions, the second peak of $H$. abietis occurrence is usually observed between early August and mid-September, resulting from the emergence of the second generation developed from the eggs laid on the roots of stumps in clear-cut areas by females of the first generation. In 2015 in both Forest Districts and in 2016 in the Garwolin Forest District, there was no clear second pest occurrence peak. Perhaps 
Fig. 4 The effect of the interaction between a stand type (OS—old stand; YS—young stand) and period of the year, b stand type and distance from the reforested area, and $\mathbf{c}$ period and distance from the reforested area on the number of $H$. abietis beetles $( \pm \mathrm{CI})$ captured in the traps set up in the stands (different letters indicate significant differences between the OSs and YSs for each term separately in a and between the slopes of the regression lines in b and c; NB_GLMM followed by contrast tests)

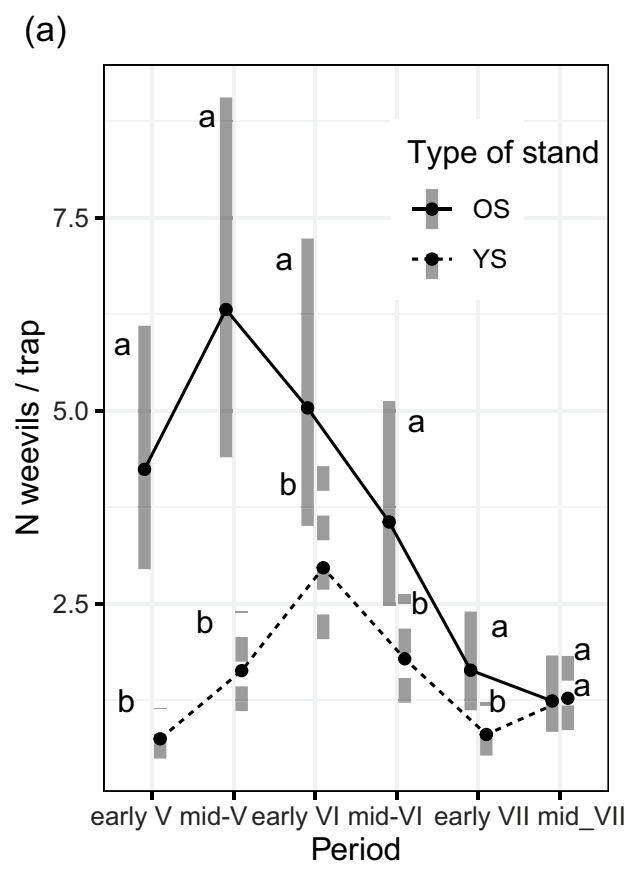

(b)

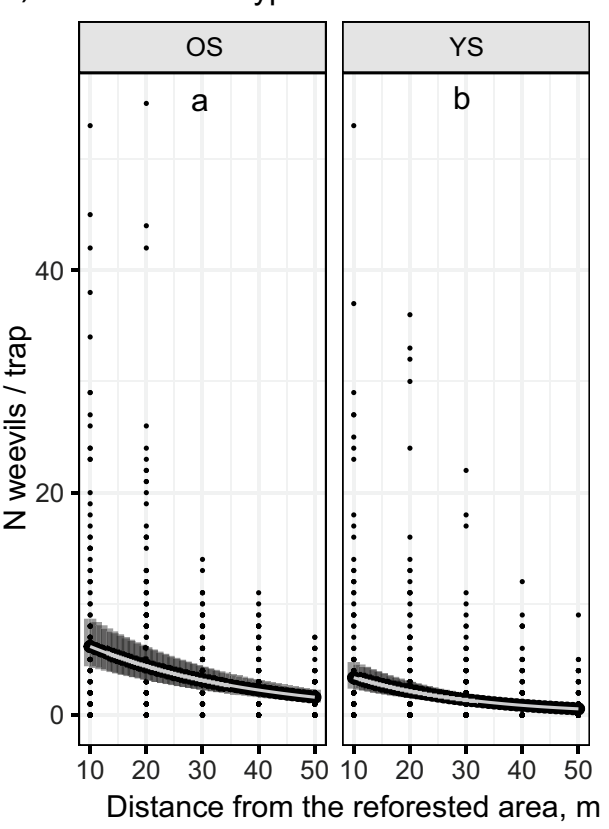

(c)

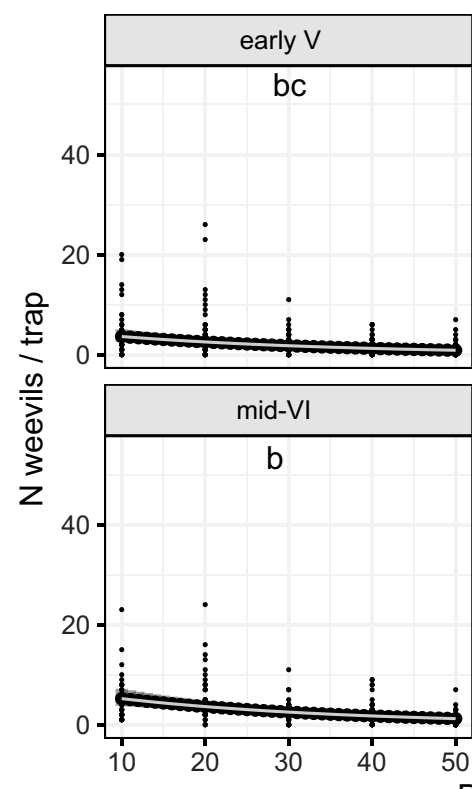

Period

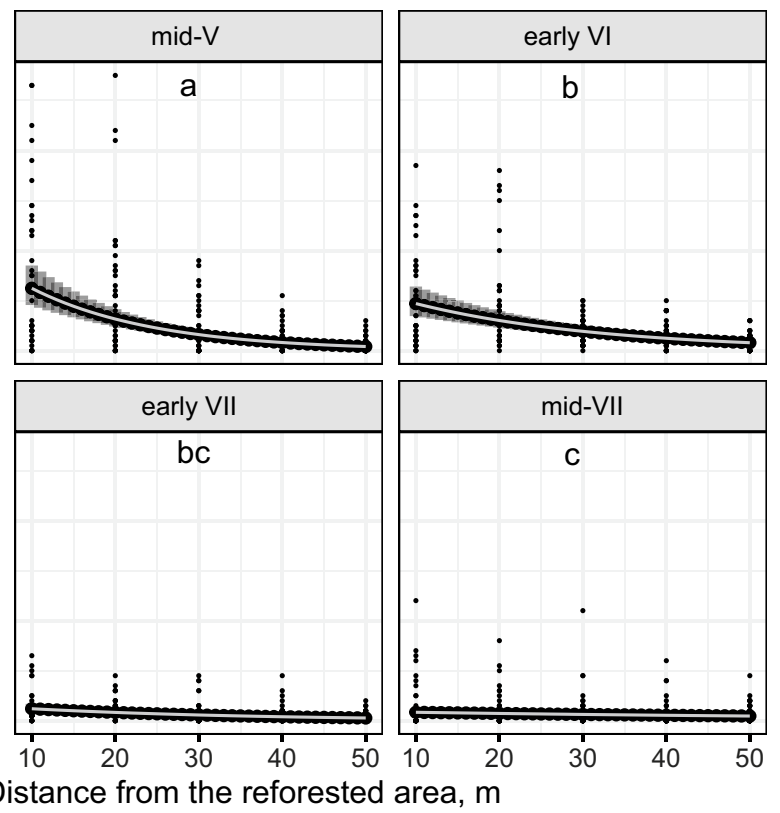

this resulted from the high daily temperatures in August and September 2015-2016, often exceeding $30{ }^{\circ} \mathrm{C}$. Such weather conditions may limit the activity of the weevils at sunny sites (e.g., clear-cut areas) to twilight and dark hours. On hot summer days, the beetles tend to leave open areas to find shelter in the canopy of mature forests (Leather et al. 1999). Christiansen and Bakke (1971) showed that large pine weevils fed most intensively when the air temperature was between $19{ }^{\circ} \mathrm{C}$ and $28{ }^{\circ} \mathrm{C}$, while temperatures above $30{ }^{\circ} \mathrm{C}$ inhibited their feeding activity. In addition, Örlander et al. (1997) stated that the decline in beetle catches in traps observed in August could result from post-reproductive weevils preparing for hibernation in soil. Nordenhem (1989) found that some beetles emerge from pupal chambers from August-September (the second peak of occurrence), but most of the population stays and overwinters within the pupal chambers. In our study, the extremely hot summer and early autumn of 2015 could explain the much lower insect catches at that time than in 2016. A slightly different course of change in the number of beetles was recorded in 
2016 in the Koniecpol Forest District. In this experimental area, high catches were continuously recorded until August, when the second pest occurrence peak was observed. The difference in these results, compared to the others, is difficult to interpret because the site characteristics of all experimental areas were similar (see Tables 1 and 2). Most likely, local microhabitat conditions impacted the dynamics of the pest population in this area. This was pointed out by Wilson et al. (1996), who stated that some changes in H. abietis numbers may originate from environmental modification of pest behaviour.

Knowledge of the spatial distribution of $\mathrm{H}$. abietis at reforested sites during the growing season is very limited. Earlier research mainly focused on the spatial distribution of seedling damage caused by the large pine weevil (Korczyński 1988; Nordlander et al. 2003c). In our study, an interesting weevil distribution pattern was observed throughout the period of insect activity. In May, the large pine weevil was more abundant along the edge of the reforestations than in the other parts, and its number decreased with increasing distance towards the centre of the reforestations. This inverse dependence of beetle catches on the distance from the edge of reforestations in May partly supports our first research hypothesis and suggests that in late spring, many beetles migrate to reforestations from neighbouring stands. The exact distance over which the beetles migrate to the reforestations is not known. In an experiment with marked individuals, some individuals were found $2 \mathrm{~km}$ from the release site (Korczyński 1992). The study by Solbreck (1980), in which flight duration was estimated in a flight mill, suggested that the majority of females in a population (>50\%) can fly up to $15 \mathrm{~km}$ during the entire flight period, and some individuals can move as far away as $80 \mathrm{~km}$. However, the Solbreck's study was conducted in the absence of breeding material, and therefore, the assessed distances should be considered as potential distances. In addition to flight behaviour, the weevils also move by crawling, and in this case, they disperse across much shorter distances, up to $50 \mathrm{~m}$ (Eidmann 1981). The method used in our study does not allow us to distinguish beetles that migrate by flying from those that migrate by crawling, but the higher abundance of $H$. abietis along the edge with the neighbouring stands suggests that the majority of the individuals captured in our traps in this zone migrated by crawling, particularly when the temperature was below $18-19{ }^{\circ} \mathrm{C}$ (Solbreck and Gyldberg 1979). If the beetles migrated only by flying from both neighbouring and distant stands, their distribution would be random.

Later in the growing season, the observed inverse relationship between the catches and the distance from the stand edge changed. In June, the beetles were distributed more regularly, while in July, the relationship became positive; i.e., more beetles were caught in the central part of the reforestations than along the edges. This may be related to the lower migration from the neighbouring stands and higher migration within the reforestations and presumably from more distant stands due to the higher temperatures enabling higher insect flight activities.

Studies of the H. abietis population abundance and distribution in neighbouring stands are scarce. Zumr and Starý (1994) compared the numbers of $H$. abietis beetles caught in 5 modified Swedish traps (Nordlander 1987) placed at $10 \mathrm{~m}$ intervals in 80 year-old $P$. sylvestris stands, 70 yearold $P$. abies stands and in a mixed 30 to 95 year old stand consisting of P. sylvestris, P. abies and Fagus sylvatica L. No differences in the numbers of beetles were found between these stands, but these numbers were not compared to the abundance of beetles in any reforestations, and the distance from the reforested clear-cut areas was not considered. Our study showed that the weevil abundance was much higher in the old stands (61-69 years old) than in the young stands (5-11 years old). The beetle catches in both types of stands increased towards the edge with the reforestations, especially in mid-May, i.e., during the period of most intense pest migration to the reforested sites. These results suggest that old stands may be considered a larger source of $H$. abietis migration to reforestations than young stands. On the other hand, there was no significant effect of either the interaction between the type of neighbouring stand and period of a year or the interaction between the type of stand and the distance from the stand on the catches of H. abietis in the reforestations. In both types of reforestations (reforestationby-old stand and reforestation-by-young stand), the catches decreased with increasing distance from the stand in May, and the relationship became positive in July. Only in June was a difference between the trends observed: an increasing trend in the catches with increasing distance from the stand occurred in the reforestations close to the old stands, and a decreasing trend occurred in the reforestations neighbouring the young stands. Therefore, we cannot confirm the second research hypothesis whereby more beetles migrate to the reforestations from the old stands than from the young stands. The availability of food sources such as thin twigs in tree crowns may have led to the larger number of large pine weevils in the old stands than in the young stands. The presence of alternative food and breeding sites in the old stands could demotivate a portion of the beetles to move from these stands and therefore may explain the absence of a significant difference between the beetle catches in the reforestations neighbouring the different types of stands. This assumption is consistent with the results obtained by von Sydow and Örlander (1994) and Örlander et al. (2000, 2001), who revealed a larger number of beetles in the crowns of mature Scots pine trees in stands adjacent to recently clear-cut areas than in the crowns of more sun-exposed mature Scots pine trees left standing in clear-cut areas providing seeds 
and shelter for natural regeneration. The 3 to $20 \mathrm{~mm}$ twigs in these crowns constituted the major food source during the maturation feeding period. When no fresh Scots pine stumps ( $\leq 1$ year old) attractive to beetles are present in the stands, the large pine weevil can also develop in thicker branches, in fragments of roots of dead trees or in pieces of bark together with their inner phloem on the ground (Munro 1928, 1929; Leather et al. 1999; Day et al. 2004). Generally, there is more suitable breeding material in old stands than in young stands, and this can increase the pest concentration in these places. In addition, old stands offer more favourable microclimatic conditions than young stands, such as lower insolation, higher humidity and, as a result, lower air temperatures, which are more favourable for the intensive feeding of beetles.

\section{Conclusions and implications for the protection of reforested areas}

The observations of the $H$. abietis abundance and spatial distribution during the growing season in the reforestations revealed the following:

- The migration of the large pine weevil to the reforestations starts at the end of April and reaches a maximum in mid-May and early June.

- Larger numbers of beetles are found in the old stands (60-69 years old) than in the young stands (5-11 years old) neighbouring the recent reforestations. This trend continues from May to early July.

- In May, the largest numbers of large pine weevils in the reforestations are concentrated close to the edge with neighbouring stands, and in June, their distribution becomes more regular, while beginning in early July, the numbers of beetles increase in the central parts of the reforestations.

Therefore, to assess the population abundance of the large pine weevil in reforestations throughout its entire active period, we recommend deploying traps along transects oriented from the edge with neighbouring stands towards the centre of the reforestations rather than deploying traps only in the central part of these sites. Our results are useful for pest monitoring improvement and the development of methods to assess the threat to new plantations.

Online Resource 1a Dynamics of the $H$. abietis catches (mean $\pm \mathrm{SE}$ ) in the IBL-4 traps (upper panel) and mean daily ambient temperature (lower panel) in the Garwolin and Koniecpol Forest Districts in 2015 (the black arrows indicate the dates of trap installation).

Online Resource 1b Dynamics of the H. abietis catches $($ mean \pm SE) in the IBL-4 traps (upper panel) and mean daily ambient temperature (lower panel) in the Garwolin and Koniecpol Forest Districts in 2016 (the black arrows indicate the dates of trap installation).

Online Resource 2 Catches of $\mathrm{H}$. abietis in the traps located in the reforestations close to either the old stands or young stands at different distances from the stand in the different periods.

\section{Author contributions}

IS contributed to all steps of the experiments and wrote the manuscript. LS performed and interpreted the statistical analysis and participated in manuscript writing. TJ, HS, and AS participated in the experimental design, field trials and data collection. All authors approved the manuscript.

supplementary Information The online version contains supplementary material available at (https://doi.org/10.1007/s10340-021-01339 $-6)$.

Funding This work was financed by the General Directorate of State Forests in Poland, Grant No. 500410.

\section{Compliance with Ethical Standards}

Conflicts of interest The authors declare that they have no conflicts of interest.

Ethics approval This research complied with all national standards for ethical conduct in research and did not involve any studies on humans or animals other than insects performed by any of the authors.

Consent to participate Informed consent was obtained from all individual participants included in the study.

Consent for publication Consent for publication was obtained from all individual participants included in the study.

Availability of data and material The datasets analysed in the current study are not publicly available due to an agreement with the General Directorate of State Forests in Poland but are available from the corresponding author upon reasonable request.

Open Access This article is licensed under a Creative Commons Attribution 4.0 International License, which permits use, sharing, adaptation, distribution and reproduction in any medium or format, as long as you give appropriate credit to the original author(s) and the source, provide a link to the Creative Commons licence, and indicate if changes were made. The images or other third party material in this article are included in the article's Creative Commons licence, unless indicated otherwise in a credit line to the material. If material is not included in the article's Creative Commons licence and your intended use is not permitted by statutory regulation or exceeds the permitted use, you will need to obtain permission directly from the copyright holder. To view a copy of this licence, visit http://creativecommons.org/licenses/by/4.0/. 


\section{References}

Bejer-Petersen B, Juutinen P, Kangas E, Bakke A, Butovitsch V, Eidmann HH, Heqvist KJ, Lekander B (1962) Studies on Hylobius abietis L. I. development and life cycles in the Nordic countries. Acta Entomol Fenn 17:1-10

Bolker BM, Brooks ME, Clark CJ, Geange SW, Poulsen JR, Stevens MHH, White J-SS (2009) Generalized linear mixed models: a practical guide for ecology and evolution. Trends Ecol Evol 24:127-135. https://doi.org/10.1016/j.tree.2008.10.008

Brooks ME, Kristensen K, van Benthem KJ, Magnusson A, Berg CW, Nielsen A, Skaug HJ, Maechler M, Bolker BM (2017) GLMM TMB balances speed and flexibility among packages for zeroinflated generalized linear mixed modeling. R J 9:378

Christiansen E (1971) Laboratory study on factors influencing premaginal development of Hylobius abietis L. (Col., Curculionidae). Nor Entomol Tidsskr 18:1-8

Christiansen E, Bakke A (1968) Temperature preference in adults of Hylobius abietis L. (Coleoptera: Curculionidae) during feeding and oviposition. Z Angew Entmol 62:83-89. https://doi. org/10.1111/j.1439-0418.1968.tb04111.x

Christiansen E, Bakke A (1971) Feeding activity of the pine weevil Hylobius abietis L. (Col., Curculionidae) during a hot period. Nor Entomol Tidsskr 18:109-111

Day KR, Nordlander G, Kenis M, Halldorson G (2004) General biology and life cycles of bark weevils. In: Lieutier F, Day KR, Battisti A, Grégoire J-C, Evans HF (eds) Bark and wood boring insects in living trees in Europe, a synthesis. Springer, Dordrecht, pp 331-349

Daegan JGI, Wainhouse D, Peace A (2012) The effect of temperature on the development and life cycle regulation of the pine weevil Hylobius abietis and the potential impacts of climate change. Agr For Entomol 14:348-357. https://doi.org/10.111 1/j.1461-9563.2012.00575.x

Dominik J (1958) Research on the development of the large pine weevil (Hylobius abietis L.) in sunny and shady areas. Sylwan 7:45-48

Eidmann H (1974) Hylobius Schőnh. In: Schwenke W (ed) Die Forstschadlinge Europas. Parey, Berlin, vol. 2, pp 275-293

Eidmann HH (1981) Pine weevil research for better reforestations. In: Proceedings of the 17th IUFRO World Congress, Division 2. Kioto, pp 441-447

Eidmann HH (1997) Assessment of pine weevil numbers on clear-cut and forest sites with shelter boards and pitfall traps. Anz Schädl Pflanz Umw 70:68-72. https://doi.org/10.1007/BF02039130

Havukkala I, Selander J (1976) Reactions of the large pine weevil, Hylobius abietis L. (Col., Curculionidae), to various light and humidity stimuli during three stages of its life cycle. Ann Entomol Fenn 42:54-62

Inward DJG, Wainhouse D, Peace A (2012) The effect of temperature on the development and life cycle regulation of the pine weevil Hylobius abietis and the potential impacts of climate change. Agric For Entomol 14:348-357. https://doi.org/10.111 1/j.1461-9563.2012.00575.x

Korczyński I (1984) Population density of the large pine weevil (Hylobius abietis L.) and the extent of damage done by it in Scotch pine (Pinus silvestris L.) plantation in dependence on the time of cutting. Sylwan 128:53-58

Korczyński I (1988) Seasonal changes in the spatial distribution of feeding by the pine weevil Hylobius abietis in Scots pine plantations. Sylwan 132:49-53

Korczyński I (1992) Studies on the ecology of the pine weevil - Hylobius abietis (L.) (Coleoptera: Curculionidae) in the aspect of new possibilities for the protection of pine crops. Rocz AR Pozn 229:23
Kuziemska-Grzeczka G (1984) Potential for and rate of development of Hylobius abietis (Col., Curculionidae) on various tree species in sunny and shaded areas. Fol For Pol For 27:49-57

Långström B (1982) Abundance and seasonal activity of adult Hylobius-weevils in reforestation areas during first years following final felling. Commun Inst For Fenn 106:2-22

Långstrőm B, Day KR (2004) Damage, control and management of weevil pests, especially Hylobius abietis. In: Lieutier F, Day KR, Battisti A, Grégoire J-C, Evans HF (eds) Bark and wood boring insects in living trees in Europe, a synthesis. Springer, Dordrecht, pp 415-444

Leather SR, Day KR, Salisbury AN (1999) The biology and ecology of the large pine weevil, Hylobius abietis (Coleoptera: Curculionidae): a problem of dispersal? Bull Entomol Res 89:3-16. https ://doi.org/10.1017/s0007485399000024

Leather SR, Small AA, Bøgh S (1995) Seasonal variation in local abundance of adults of the large pine weevil, Hylobius abietis L. (Col., Curculionidae). J Appl Entomol 119:511-513. https:// doi.org/10.1111/j.1439-0418.1995.tb01327.x

Lenth R (2020) emmeans: Estimated Marginal Means, aka LeastSquares Means. R package version 1(4):5

López-Villamor A, Carreňo S, López-Villamor X, Suárez-Vidal E, Sampedro L, Nordlander G, Bjőrklund N, Zas R (2019) Risk of damage by the pine weevil Hylobius abietis in southern Europe: Effects of silvicultural and landscape factors. For Ecol Manag 444:290-298. https://doi.org/10.1016/j.foreco.2019.04.027

Mangiafico SS (2016) Summary and analysis of extension program evaluation in $\mathrm{R}$, version 1.15.0. http://rcompanion.org/docum ents/RHandbookProgramEvaluation.pdf. Accessed 13 December 2018

Manlove JD, Styles J, Leather SR (1997) Feeding of the adults of the large pine weevil, Hylobius abietis (Coleoptera: Curculionidae). Eur J Entomol 94:153-156

Moore R (2001) Emergence trap developed to capture adult large pine weevil Hylobius abietis (Coleoptera: Curculionidae) and its parasite Bracon hylobii (Hymenoptera: Braconidae). Bull Entomol Res 91:109-115

Moore R, Brixey JM, Milner AD (2004) Effect of time of year on the development of immature stages of the large pine weevil (Hylobius abietis L.) in stumps of Sitka spruce (Picea sitchensis Carr.) and influence of felling date on their growth, density and distribution. J Appl Entomol 128:167-176. https://doi.org/10.11 11/j.1439-0418.2004.00828.x

Munro JW (1928) The biology an control of Hylobius abietis L. Forestry 2:31-39

Munro JW (1929) The biology and control of Hylobius abietis L. Part II Forestry 3:61-65

Nordenhem H (1989) Age, sexual development, and seasonal occurrence of the pine weevil Hylobius abietis (L.). J Appl Entomol 108:260-270. https://doi.org/10.1111/j.1439-0418.1989.tb004 $56 . \mathrm{x}$

Nordenhem H, Eidmann HH (1991) Response of the pine weevil Hylobius abietis L. (Col., Curculionidae) to host volatiles in different phases of its adult life cycle. J Appl Entomol 112:353-358. https ://doi.org/10.1111/j.1439-0418.1991.tb01067.x

Nordlander G (1987) A method for trapping Hylobius abietis (L.) with a standardized bait and its potential for forecasting seedling damage. Scand J For Res 2:199-213. https://doi.org/10.1080/02827 588709382458

Nordlander G (1989) The use of artificial baits to forecast seedling damage caused by Hylobius abietis (Coleoptera: Curculionidae). In: Alfaro RI, Glover SG (eds) Insects affecting reforestation: biology and damage. Victoria, Canada, Pacific and Yukon Region, Forestry Canada, pp 34-35 
Nordlander G, Nordenhem H, Bylund H (2002) Oviposition patterns of the pine weevil Hylobius abietis. Entomol Exp Appl 85:1-9. https://doi.org/10.1046/j.1570-7458.1997.00229.x

Nordlander G, Bylund H, Örlander G, Wallertz K (2003a) Pine weevil population density and damage to coniferous seedlings in a regeneration area with and without shelterwood. Scand J For Res 18:438-448. https://doi.org/10.1080/02827580310001634

Nordlander G, Orlander G, Langvall O (2003b) Feeding by the pine weevil Hylobius abietis in relation to sun exposure and distance to forest edges. Agric For Entomol 5:191-198. https://doi.org/10 $.1046 /$ j.1461-9563.2003.00185.x

Olenici N, Duduman ML, Teodosiu M, Olenici V (2016) Efficacy of artificial traps to prevent the damage of conifer seedlings by large pine weevil (Hylobius abietis L.) - a preliminary study. Bull Transilv Univ Bras For Wood Ind Agric Food Eng Ser II 9:9-20

Örlander G, Nilsson U, Nordlander G (1997) Pine weevil abundance on clear-cuttings of different ages: a 6-year study using pitfall traps. Scand J For Res 12:225-240. https://doi.org/10.1080/02827 589709355405

Örlander G, Nordlander G, Wallertz K (2001) Extra food supply decreases damage by the pine weevil Hylobius abietis. Scand J For Res 16:450-454. https://doi.org/10.1080/02827580152632847

Örlander G, Nordlander G, Wallertz K, Nordenhem H (2000) Feeding in the crowns of Scots pine trees by the pine weevil Hylobius abietis. Scand J For Res 15:194-201. https://doi.org/10.1080/02827 5800750015000

R Core Team (2018) R: a language and environment for statistical computing, v. 3.5.1. R Foundation for Statistical Computing, Vienna, Austria

R Studio Team (2016) RStudio: integrated development for R, Version 1.1.463. RStudio, Inc., Boston, MA

Schlyter F (2004) Semiochemicals in the life of bark feeding weevils. In: Lieutier F, Day KR, Battisti A, Grégoire J-C, Evans HF (eds) Bark and wood boring insects in living trees in Europe, a synthesis. Springer, Dordrecht, pp 351-364

Skłodowski J, Gadziński J (2001) Effectiveness of beetle catches in two types of traps for Hylobius abietis. Sylwan 6:55-63

Skrzecz I (2001) Large pine weevil (Hylobius abietis L.) abundance and the extent of damage in plantations established on clearcuts with pine stumps treated with the fungus Phlebiopsis gigantea (Fr.: Fr.) Jülich. Fol For Pol For 43:137-151

Skrzecz I (2017) Insects associated with reforestation and their management in Poland. In: Shields DCV (ed) Biological control of pest and vector insects. InTech Open, London, UK, pp 133-168

Solbreck C (1980) Dispersal distances of migrating pine weevils, Hylobius abietis, Coleoptera: Curculionidae. Entomol Exp Appl 28:123-131. https://doi.org/10.1111/j.1570-7458.1980.tb02997.x

Solbreck C, Gyldberg B (1979) Temporal flight pattern of the large pine weevil, Hylobius abietis L. (Col., Curculionidae), with special reference to the influence of weather. Z Angew Entomol 88:532-536. https://doi.org/10.1111/j.1439-0418.1979.tb02532.x

Szmidt A, Korczyński I (1982) Population density of the pine weevil Hylobius abietis L., and its feeding activity, as indices for forecasting damage. Pr Kom Nauk Rol Kom Nauk Lesn 54:137-144
Thorpe KV, Day KR (2002) The impact of host plant species on the larval development of the large pine weevil Hylobius abietis L. Agric For Entomol 4:187-194. https://doi.org/10.104 6/j.1461-9563.2002.00144.x

Tilles DA, Sjödin K, Nordlander G, Eidmann HH (1986) Synergism between ethanol and conifer host volatiles as attractants for the pine weevil, Hylobius abietis (L.) (Coleoptera: Curculionidae). J Econ Entomol 79:970-973. https://doi.org/10.1093/jee/79.4.970

Toivonen R, Viiri H (2006) Adult large pine weevils Hylobius abietis feed on silver birch Betula pendula even in the presence of conifer seedlings. Agric For Entomol 8:121-128. https://doi.org/10.111 $1 / j .1461-9563.2006 .00290 . x$

von Sydow F, Örlander G (1994) The influence of shelterwood density on Hylobius abietis (L.) occurrence and feeding on planted conifers. Scand J For Res 9:367-375. https://doi.org/10.1080/02827 589409382853

von Sydow F, Birgersson G (1997) Conifer stump condition and pine weevil (Hylobius abietis) reproduction. Can J Res 27:1254-1262. https://doi.org/10.1139/x97-089

Wallertz K, Nordenhem H, Nordlander G (2014) Damage by the pine weevil Hylobius abietis to seedlings of two native and five introduced tree species in Sweden. Silva Fenn 48:1188

Wickham H (2016) Ggplot2: elegant graphics for data analysis. Springer-Verlag, New York

Wilson WL, Day KR (1995) The comparative effectiveness of chemical traps, and fir, spruce and larch billets, for the estimations of pine weevil (Hylobius abietis L.) (Col., Curculionidae) density indices. J Appl Entomol 119:157-160. https://doi. org/10.1111/j.1439-0418.1995.tb01263.x

Wilson WL, Day KR, Hart EA (1996) Predicting the extent of damage to conifer seedlings by the pine weevil (Hylobius abietis L.): a preliminary risk model by multiple logistic regression. New For 12:203-222

Zumr V, Starý P (1993) Baited pitfall and flight traps in monitoring Hylobius abietis (L.) (Col., Curculionidae). J Appl Entomol 115:454-461. https://doi.org/10.1111/j.1439-0418.1993.tb004 14.X

Zumr V, Starý P (1994) Monitoring of seasonal occurrence of Hylobius abietis (L.) (Col., Curculionidae) in different forest environments of a model area. J Appl Entomol 118:361-364. https://doi. org/10.1111/j.1439-0418.1994.tb00812.x

Zumr V, Starý P (1995) Monitoring Hylobius abietis (L.) (Col., Curculionidae by baited pitfall traps in relation to planting and treatment od seedlings in re-forested area. Anz Schädlingskd Pfl 68:18-21. https://doi.org/10.1007/BF01980351

Zuur A, Ieno E, Walker N, Saveliev A, Smith G (2009) Mixed effects models and extensions in ecology with R. Springer Science+Business Media, New York

Publisher's Note Springer Nature remains neutral with regard to jurisdictional claims in published maps and institutional affiliations. 